- Resolution on US Policy on Highly Migratory Species

International Law Association

- Rules of International Law Applicable to Transfrontier Pollution

Canada

- Seal Products

China

- Environmental Protection Law

Germany, F.R.

- Speech of Mostafa K. Tolba to the 'Umweltforum' (Extracts)
26 India

- Draft: National Forest Policy (Extracts)

27 - Prime Minister's Inaugural Address at the Conference of State Forest Ministers

Red Sea Convention (Regional Conference of Plenipotentiares on the Conservation of the Marine Environment and

Coastal Areas in the Red Sea and Gulf of Aden

74 IUCN

- Declaration of the World National Parks Congress 62

73 - Recommendations of the World National Parks Congress 63

Convention on Wetlands of International Importance Especially as Waterfowl Habitat

\title{
AUTHOR INDEX OF VOLUME 10
}

Brady, Gordon L., 3

Brown, E.D., 122

Heimsoeth, Harald, 34

Knebel, Jürgen, 47

Meiners, Hubert, 17
Smets, Henri, 52

Stevens, Neil, 13

Suetens, L.-P., 137

Treves, Tullio, 78

Uppenbrink, Martin, 47 